\title{
UPAYA MENINGKATKAN HASIL BELAJAR SISWA DENGAN MENGGUNAKAN METODE CONTEXTUAL TEACHING LEARNING MATA PELAJARAN PKN DI KELAS VIII-3 SMP NEGERI 8 TEBING TINGGI
}

\author{
Aspin Aruan \\ Surel : aspinaruan18@gmail.com
}

\begin{abstract}
ABSTRAK
Masalah yang dihadapi dalam penelitian ini adalah masalah rendahnya hasil belajar siswa pada pelajaran PKn di Kelas VIII SMP Negeri 8 Tebing Tinggi. Penelitian ini bertujuan untuk mengetahui keegektifan penggunaan metode Contextual Teaching Learning dalam meningkatkan hasil belajar siswa. Alat yang digunakan untuk mengumpulkan data adalah daftar nilai siswa. Berdasarkan tes awal (pre test) dari 30 siswa terdapat 27 orang siswa yang mendapatkan hasil belajar rendah (belum tuntas). Kemudian pada siklus I terdapat 10 orang siswa yang termasuk pada kategori tuntas. Pada siklus II terdapat 23 orang siswa termasuk dalam kategori tuntas. Hasil penelitiaanmenunjukkan sudah terjadinya peningkatan yang signifikan.
\end{abstract}

Kata kunci: Hasil belajar, Contextual Teaching Learning

\section{PENDAHULUAN}

Masalah

yang

dihadapi pendidikan adalah masalah lembaga proses pembelajaran. Dalam proses pembelajaran anak kurang didorong untuk mengembangkan kemampuan berfikirnya, untuk itu guru dituntut harus mampu mengelola proses belajar mengajar yang memberikan rangsangan kepada siswa karena siswalah yang menjadi subjek utama dalam belajar.

Seorang guru tidak akan dapat melaksanakan tugasnya bila dia tidak menguasai satu pun metode mengajar yang dirumuskan dan dikemukakan para ahli psikologi dan pendidikan (Djamarah dkk, 2006:72).

Jika guru dapat menggunakan metode secara optimal dan mengaitkan materi pelajaran dengan lingkungan sekitar siswa maka siswa akan termotivasi dan hasil belajar siswa akan meningkat.Hal ini dapat dilihat dari nilai raport yang diperoleh dari guru Kelas VIII. Nilai yang diperoleh siswa tidak mencapai KKM yaitu 70. Hal ini disebabkan karena siswa kurang dilatih berfikir kritis, kreatif dan inovatif sehingga hasil belajar siswa rendah dan metode yang digunakan guru dalam pembelajaran PKN kurang bervariasi. Guru cenderung menggunakan metode ceramah tanpa disertai dengan penggunaan media sehingga siswa cenderung pasif terhadap materi yang dijelaskan guru. Kepasifan siswa dalam belajar merupakan pertanda kurang baik dalam proses pembelajaran juga dalam perkembangan intelektual siswa. Siswa menjadi malas belajar, 
berfikir dan malas berkompetensi saat belajar sehingga akan mengakibatkan terciptanya siswa yang tidak terampil serta berintelektual dalam pembelajaran PKN siswa harus berfikir kritis, kreatif dan inovatif karena PKN adalah bidang studi yang mempelajari, menelaah, menganalisis gejala serta masalah sosial di masyarakat dengan meninjau dari berbagai aspek kehidupan dimasyarakat. Adapun kompetensi dasar dari materi yang akan diteliti yaitu konstitusi di Indonesia.Berdasarkan uraian di atas, maka peneliti tertarik untuk melakukan penelitian yang berjudul "Upaya Meningkatkan Hasil Belajar Siswa pada Mata Pelajaran PKn Menggunakan Metode Contextual Teaching Learning di Kelas VIII SMP Negeri 8 Tebing Tinggi T.A. 2016/2017."

Muhabbin Syah (2003:213) menyatakan "Hasil belajar merupakan penguasaan hubungan yang diperoleh sehingga seseorang itu dapat menampilkan pengalaman dan penguasaan bahan pelajaran yang telah dipelajari”. Dimyanti (2006: 250-251) menyatakan bahwa "Hasil belajar merupakan hal yang dapat dipandang dari dua sisi yaitu dilihat dari sisi siswa dan guru". Dari sisi siswa hasil belajar merupakan tingkat perkembangan mental yang lebih baik bila dibandingkan dengan saat sebelum proses belajar mengajar sedangkan dari sisi guru hasil belajar merupakan saat terselesaikannya bahan pelajaran tersebut.
Menurut Slameto (2010: 54) "Hasil belajar siswa dipengaruhi oleh beberapa faktor, yang dapat dibedakan menjadi dua faktor utama, yaitu faktor intern dan faktor eksternal". Faktor intern adalah faktor yang ada dalam diri individu yang sedang belajar, sedangkan faktor ekstern adalah faktor yang ada diluar diri individu tersebut. Faktor intern dapat dikelompokkan menjadi tiga faktor yaitu faktor jasmaniah, faktor psikologis dan faktor kelelahan. Faktor jasmaniah meliputi faktor kesehatan dan cacat tubuh. Sedangkan Faktor psikologis meliputi intelegensi, perhatian, minat, bakat, motif, kematangan, dan kesiapan. Faktor ekstern dapat dikelompokkan menjadi tiga faktor, yaitu faktor keluarga, faktor sekolah, dan faktor masyarakat. Faktor keluarga meliputi cara orang tua mendidik, relasi antar anggota keluarga, suasana rumah, keadaan ekonomi keluarga, pengertian orang tua, latar belakang kebudayaan. Faktor sekolah meliputi metode mengajar, kurikulum, relasi guru dengan siswa, relasi siswa dengan siswa, disiplin sekolah, alat pelajaran, waktu sekolah, standar pelajaran diatas ukuran, keadaan gedung, metode belajar dan tugas rumah. Sedangkan Faktor masyarakat meliputi kegiatan siswa dalam masyarakat, mass media, teman bergaul, dan bentuk kehidupan masyarakat.

Dalam kegiatan belajar mengajar daya serap peserta didik tidaklah sama. Dalam menghadapi 
perbedaan tersebut, strategi pengajaran yang tepat sangat dibutuhkan. Contextual Teaching and Learning (CTL) merupakan proses pembelajaran holistik yang bertujuan untuk membelajarkan peserta didik dalam memahami bahan ajar secara bermakna yang dikaitkan dengan konteks kehidupan nyata, baik berkaitan dengan lingkungan pribadi, agama, sosial, ekonomi, maupun kultural. Sehingga peserta didik memperoleh ilmu pengetahuan dan keterampilan yang dapat diaplikasikan dan ditansfer dari suatu konteks permasalahan yang satu kepermasalahan yang lainnya.Ada tujuh komponem pembelajaran kontekstual sehingga bisa dibedakan dengan model lainnya, yaitu: (1) Kontruktivisme, (2) Inkuiri (menemukan),

Bertanya (Questioning),

Masyarakat belajar

(LearningComunity), (5) Pemodelan (Modeling), (6) Refleksi, (7) Penilaian Nyata (Authentic Assesment)

Dari latar belakang telah tergambar permasalahan yang timbul di dalam penelitian ini adalah:

a. Rendahnya hasil belajar siswa dalam pembelajaran PKN pokok bahasan Ketaatan Terhadap Perundang-undangan Nasional di Indonesia.

b. Metode pembelajaran yang diterapkan guru dikelas kurang bervariasi sehingga terkesan membosankan.

Adapun rumusan masalah dalam penelitian ini adalah "Apakah dengan menggunakan metode Contextual Teaching Learning (CTL) dapat meningkatkan hasil belajar siswa pada Pokok Bahasan Ketaatan Terhadap Perundangundangan Nasional di Indonesia di Kelas VIII SMP Negeri 8 Tebing Tinggi T.A 2016/2017 ?"

Adapun tujuan penelitian ini adalah untuk mengetahui apakah dengan menggunakan metode Contextual Teaching Learning (CTL) dapat meningkatkan hasil belajar siswa pada Pokok Bahasan Ketaatan Terhadap Perundangundangan Nasional di Indonesia di Kelas VIII SMP Negeri 8 Tebing Tinggi T.A 2016/2017”.

\section{METODE PENELITIAN}

Jenis penelitian yang akan dilaksanakan adalah Penelitian Tindakan Kelas (PTK). Penelitian ini memiliki beberapa tahap yang berupa siklus. Prosedur penelitian terdiri dari dua siklus, setiap siklus disesuaikan dengan perubahan yang akan dicapai.

Penelitian tindakan kelas (PTK) akan dilaksanakan di kelas VIII SMP Negeri 8 Tebing Tinggi T.A 2016/2017. Subjek penelitian adalah siswa Kelas VIII yang berjumlah 36 siswa.

Penelitian ini dilaksanakan selama 3 bulan (mulai kesiapan mengajar sampai pelaksanaan tindakan), yaitupadabulan Juli, Agustus,dan September T.A 2016/2017.

$\begin{array}{llr}\text { Penelitian } & \text { ini } & \text { akan } \\ \text { dilaksanakan } & \text { sesuai } & \text { dengan }\end{array}$


perubahan yang akan dicapai. Penelitian tindakan kelas akan dilakukan dengan 2 siklus, yakni siklus I dan siklus II diantaranya :

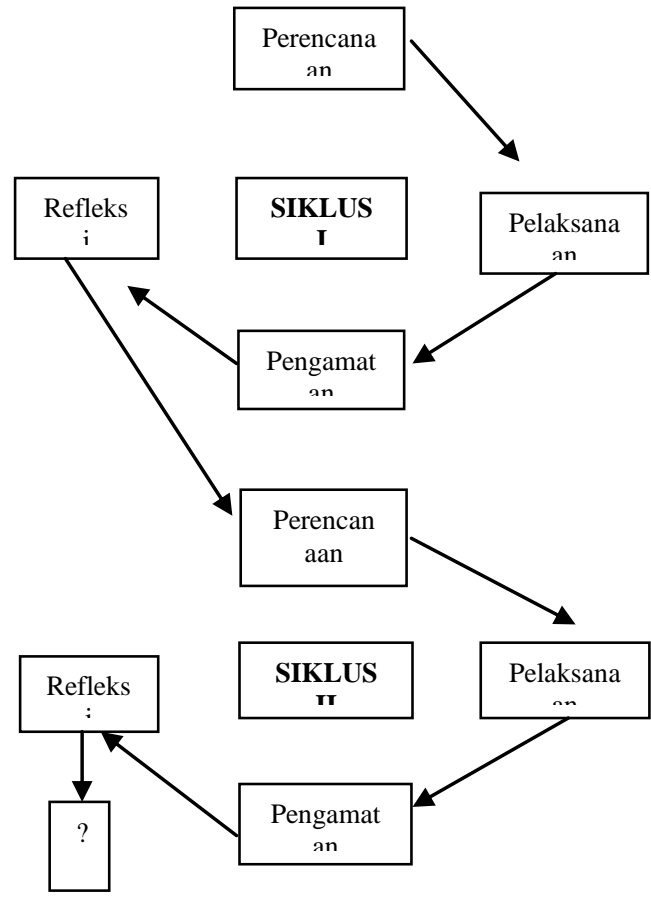

\section{Gambar Model Desain Tindakan Kelas Kemmis (dalam Arikunto 2006:16)}

Pada tahap ini yaitu Siklus I, kegiatan yang akan dilakukan adalah merencanakan tindakan yaitu penyusunan sekenario pembelajaran dengan materi konstitusi di Indonesia dengan menerapkan metode pembelajaan CTL. Perencanaan yang akan dilakukan yaitu:

a. Melakukan tes awal, untruk mengetahui kemampuan awal siswa sebelum kegiatan belajar mengajar dimulai.

b. Menyusun Rencana Pelaksanaan Pembelajaran (RPP).

c. Mempersiapkan metode pembelajaran CTL. d. Mempersiapkan alat, bahan, dan media pembelajaran

e. Membuat lembar observasi

f. menyusun alat evaluasi

Pada tahap ini kegiatan yang akan dilakukan adalah:

a. Ada penyampaian tujuan pembelajaran yang harus dicapai.

b. Memotivasi siswa untuk berpartisivasi pada mata Pelajaran PKn.

c. Penyampaian materi pelajaran tentang konstitusi di Indonesia dengan menggunakan metode contextual teaching learning.

a. d.Menjelaskan beberapa contoh (konstitusi di Indonesia).

d. Memberikan kesempatan kepada siswa untuk bertanya.

e. Membagi siswa menjadi beberapa kelompok serta memberikan tugas.

f. Menyuruh siswa membacakan hasil diskusi kelompoknya.

Kegiatan yang akan
dilaksanakan pada tahap ini
adalahpelaksanaan tindakan dan proses mengamati pembelajaran dengan menggunakan lembar observasi dan tes yang telah disiapkan. Observasi terhadap pelaksanaan metode contextual teaching learning dilaksanakan selama proses pembelajaran berlangsung, yang berkenaan dengan aktivitas belajar (memotivasi siswa dalam belajar).

Refleksi akan dilakukan berdasarkan hasil analisis data dasar hasil observasi maupun data 
evaluasi. Refleksi akan dilakukan dengan tujuan untuk menilai apakah penggunaan metode CTL sudah berjalan secara efektif, dan yang terpenting tindakan ini akan dilakukan untuk mengetahui kelemahan - kelemahan atau kendala yang dihadapi guru dalam meningkatkan hasil belajar siswa pada mata Pelajaran PKn (Pendidikan KewargaNegaraan) melalui model pembelajaran CTL.

Pada tahap ini yaitu Siklus II, kegiatan yang akan dilakukan, antara lain:

a. Melakukan tes awal, untruk mengetahui kemampuan awal siswa sebelum kegiatan belajar mengajar dimulai.

b. Menyusun Rencana Pelaksanaan Pembelajaran (RPP).

c. Mempersiapkan metode pembelajaran CTL.

d. Mempersiapkan alat, bahan, dan media pembelajaran

e. Membuat lembar observasi

f. Menyusun alat evaluasi

Pada tahap ini kegiatan yang dilakukan adalah:

a. Mengkondisikan kelas (mempersiapkan siswa untuk memulai pelajaran)

b. Ada penyampaian tujuan pembelajaran yang harus dicapai, sebelum memulai pelajaran

c. Memotivasi siswa untuk berpartisipasi pada mata Pelajaran PKn

d. Menyampaikan materi pelajaran tentang konstitusi di Indonesia dengan metode pembelajaran Contextual Teaching Learning.

e. Memberikan kesempatan kepada siswa untuk bertanya.

f. Membagi siswa menjadi beberapa kelompok serta memberikan tugas kepada siswa.

g. Menyuruh perwakilan dari kelompok untuk membacakan hasil diskusinya serta menyuruh kelompok lain untuk bertanya.

Pada tahap ini pelaksanaan tindakan dan proses mengamati pembelajaran dengan menggunakan lembar observasi dan tes yang telah disiapkan. Observasi terhadap pelaksanaan metode contextual teaching learning dilaksanakan selama proses pembelajaran berlangsung, yang berkenaan dengan aktivitas belajar serta memotivasi siswa dalam belajar.

Refleksi dilakukan pada setiap akhir pertemuan selama siklus II. Tahap ini mengamati segala sesuatu yang terjadi dikelas pada pertemuan kedua.

\section{HASIL PENELITIAN DAN PEMBAHASAN}

Pada pertemuan awal, sebelum dilaksanakan pembelajaran Contextual Teaching Learning siswa diberikan pre-tes yang bertujuan untuk mengetahui kemampuan awal siswa pada Pokok Bahasan Ketaatan Terhadap Perundangan-undangan Nasional di Indonesia. Bentuk tes yang digunakan adalah esay tes sebanyak 10 soal. Setelah selesai membagikan soal, guru memberikan 
petunjuk kepada siswa untuk menuliskan jawaban pada soal tersebut serta menuliskan nama dan kelas. Kemudian siswa mengerjakan soal tersebut. Hasil pretes siswa menunjukkan bahwa hasil belajar siswa masih tergolong rendah.

Berdasarkan pelaksanaan tes awal dapat dinyatakan bahwa dari 30 siswa diperoleh nilai sebagai berikut:

a. Yang memperoleh nilai 0,67 sebanyak 6 siswa dengan persentase $20 \%$

b. Yang memperoleh nilai 2 sebanyak 8 siswa dengan persentase 26,66\%

c. Yang memperoleh nilai 3,34 sebanyak 5 siswa dengan persentase $16,66 \%$

d. Yang memperoleh nilai 4,67 sebanyak 3 siswa dengan persentase $10 \%$

e. Yang memperoleh nilai 6 sebanyak 5 siswa dengan persentase 16,66\%

f. Yang memperoleh nilai 7,34 sebanyak 3 siswa dengan persentase $10 \%$

Berdasarkan tes awal di atas dapat disimpulkan bahwa siswa masih mengalami kesulitan dalam menyelesaikan soal dan kurang memahami Pokok Bahasan Ketaatan Terhadap Perundangan-undangan Nasional di Indonesia. Kesulitan tersebut diakibatkan:

a. Siswa kurang memahami tentang materi konstitusi di Indonesia. b. Siswa kurang mampu membedakan antara usaha pertanian dan usaha perkebunan.

c. Masih banyak siswa bermainmain pada saat menjawab soal yang diberikan.

Dengan demikian dapat dinyatakan bahwa kemampuan awal siswa Kelas VIII masih rendah dalam memahami Pokok Bahasan Ketaatan Terhadap Perundangan-undangan Nasional di Indonesia.

Pada akhir siklus dilakukan refleksi terhadap seluruh materi yang telah diajarkan guru kepada siswa. Refleksi dilakukan pada akhir pertemuan siklus I setelah semua materi diajarkan. Siswa diberikan tes untuk mengetahui hasil-hasil yang diperoleh guru melalui pembelajaran Contextual Teaching Learning dan juga untuk mengetahui tingkat penguasan siswa mengenai sub Pokok Bahasan Ketaatan Terhadap Perundang-undangan Nasional di Indonesia di Kelas VIII SMP Negeri 8 Tebing Tinggi. Data-data yang diperoleh pada siklus I ini akan dijadikan acuan untuk perbaikan pada siklus II untuk dapat meningkatkan pemahamn siswa tentang Perundang-undangan di Indonesia sehingga hasil belajar siswa pada Pelajaran PKn dapat meningkat.

Dari data hasil tes siklus I di atas dapat diketahui bahwa hasil belajar siswa Kelas VIII sudah meningkat dibandingkan dengan hasil tes awal. Tetapi hasil belajar pada siklus I masih tergolong rendah 
dengan rata-rata 5,69. Berdasarkan penelitian di atas dapat dinyatakan bahwa dari 30 siswa diperoleh nilai sebagai berikut:

a. Yang memperoleh nilai 3,34 sebanyak 6 siswa dengan persentase $20 \%$

b. Yang memperoleh nilai 4,67 sebanyak 9 siswa dengan persentase $30 \%$

c. Yang memperoleh nilai 6 sebanyak 3 siswa dengan persentase $10 \%$

d. Yang memperoleh nilai 7,34 sebanyak 10 siswa dengan persentase 33,33\%

e. Yang memperoleh nilai 8,67 sebanyak 2 siswa dengan persentase $6,66 \%$.

Dari hasil analisis yang dilakukan dapat disimpulkan bahwa dari hasil pengamatan dalam tindakan sudah terlihat lebih baik dari siklus sebelumnya. Dilihat dari pengamatan selama proses pembelajaran berlangsung siswa sudah memahami maksud dan tujuan pembelajaran yang diajarkan. Hasil observasi siswa menunjukkan bahwa tingkat aktivitas belajar siswa mengalami peningkatan, dimana siswa sudah berani berinteraksi dengan guru dan mempertanyakan serta menjawab setiap pertanyaan guru. Dari data-data ini akan dijadikan acuan untuk mencukupkan kegiatan tersebut dengan tidak melanjutkan pada siklus berikutnya.

Dari hasil pengamatan tindakan yang dilakukan guru penggunaan metode Contextual
Teaching Learning dalam pembelajaran pada Pokok Bahasan Ketaatan Terhadap Perundangundangan Nasional di Indonesia yang dilakukan dalam pembelajaran sudah dikatakan optimal. Dapat dilihat bahwa adanya peningkatan hasil belajar dibandingkan dengan hasil belajar pada pre tes dan pos test siklus I, dimana pada siklus II ini nilai rata-rata yang diperoleh siswa mencapai 7,42 ( 23 orang ) dikatakan sudah tuntas dalam belajar dan persentase ketuntasannya 76,6\%. Dengan demikian, pada siklus II ini telah mencapai ketuntasan secara optimal, sehingga tidak perlu melakukan tindakan pembelajaran ke siklus berikutnya. Berikut ini disajikan persense nilai siswa pada postes siklus II.

Berdasarkan hasil dan pembahasan penelitian, maka ditemukan hal-hal sebagai berikut:

a. Pada tahap awal observasi masalah yang ditemukan guru adalah rendahnya hasil belajar siswa dalam pembelajaran PKn khususnya pada Pokok Bahasan Ketaatan Terhadap Perundangundangan Nasional di Indonesia, hal ini disebabkan oleh penggunaan metode yang kurang bervariasi sehingga siswa mudah merasa bosan dalam belajar.

b. Nilai hasil belajar siswa pada tahap tes awal sebelum diterapkan metode CTL dalam pembelajaran yang bertujuan untuk mengetahui sejauh mana tingkat pemahaman siswa terhadap materi pembelajaran 
yaitu Perundang-undangan di Indonesia pada mata Pelajaran PKn masih sangat rendah dengan arti masih banyak siswa yang belum mencapai ketuntasan dalam belajar. Dimana jumlah siswa yang berhasil mencapai atau sebanyak 6 orang dari 30 orang siswa.

\section{Pembahasan}

Berdasarkan temuan guru yang telah diuraikan, pelaksanaan pembelajaran pada pokok bahasan perundang-undangan di Indonesia dengan menggunakan metode Contextual Teaching Learning dalam proses pembelajaran menciptakan suasana aktif bagi siswa. Dengan menggunakan metode ini siswa dapat lebih fokus dan bersemangat dalam belajar karena pada pembelajaran Contextual Teaching Learning materi pelajaran dihubungkan dengan situasi nyata siswa sehingga siswa semakin aktif dalam belajar.

Pelaksanaan pembelajaran dengan menggunakan metode Contextual Teaching Learning dalam proses pembelajaran sudah terlaksana secara optimal. Dikatakan optimal karena langkah-langkah penerapan metode Contextual Teaching Learning sudah terlaksana sepenuhnya pada tahap tindakan. Sehingga hasil belajar siswa dikatakan meningkat mulai dari pre test (tes awal), postes I dan pos tes II.

\begin{tabular}{|c|c|c|c|}
\hline Aspek & $\begin{array}{c}\text { Jumlah } \\
\text { Siswa }\end{array}$ & $\begin{array}{c}\text { Nilai } \\
\text { Rata- } \\
\text { Rata }\end{array}$ & Ketuntasan \\
\hline Pretes & 3 & 3,51 & $10 \%$ \\
\hline $\begin{array}{c}\text { Postessiklus } \\
\text { I }\end{array}$ & 10 & 5,69 & $33,33 \%$ \\
\hline $\begin{array}{c}\text { Postessiklus } \\
\text { I }\end{array}$ & 23 & 7,42 & $76,6 \%$ \\
\hline
\end{tabular}

\section{SIMPULAN}

Berdasarkan pembahasan yang telah dipaparkan dapat disimpulkan bahwa:

a. Dengan menerapkan metode Contextual Teaching Learning pada materi Ketaatan Terhadap Perundang-undangan Nasional di Indonesia di Kelas VIII SMP Negeri 8 Tebing Tinggi dapat meningkatkan hasil belajar siswa. Mulai dari tes awal sampai postes siklus II.

b. Pada tes awal sebanyak 3 orang siswa $(10 \%)$ yang tuntas dalam belajar dengan rata-rata 3,42 . Pada siklus I sebanyak 10 orang siswa $(33,33 \%)$ yang tuntas dalam belajar dengan rata-rata 5,69. Pada siklus II sebanyak 23 orang siswa $(76,6 \%)$ yang tuntas dalam belajar dengan rata-rata 7,42 .

c. Metode Contextual Teaching Learning mengaitkan materi pelajaran dengan lingkungan sekitar siswa sehingga mendorong siswa membuat hubungan antara pengetahuan yang dimilikinya dengan penerapannya dalam kehidupan sehari-hari mereka. Siswa dalam belajar tidak hanya sekedar 
menghafal atau mengingat fakta karena itu akan mudah dilupakan siswa.

\section{DAFTAR RUJUKAN}

Arikunto, dkk. 2006. Penelitian Tindakan Kelas. Jakarta: Bumi Aksara.

Djamarah, dkk. 2006. Stategi Belajar Mengajar. Jakarta:PT Rineka Cipta.

Hamalik. 2010. Kurikulum dan Pembelajaran. Jakarta:Bumi Aksara.
Sanjaya, W. 2010. Strategi Pembelajaran Berorientasi Standar Proses Pendidikan. Jakarta: Kencana.

Slameto. 2010. Belajar dan FaktorFaktor Yang Mempengaruhinya. Jakarta:Rineka Cipta.

Sudjana, N. 2009. Penilaian Hasil Proses Belajar Mengajar. Bandung: PT Remaja Rosdakarya.

Syah, Muhabbin. 2003. Psikologi Belajar. Jakarta: Grapindo Persada 